\title{
Student Privacy: A Key Piece of the Online Student Satisfaction Puzzle
}

\author{
Denise Williams \\ University of Tennessee Martin \\ Ashley Kilburn \\ University of Tennessee Martin \\ Brandon Kilburn \\ University of Tennessee Martin \\ Kevin Hammond \\ University of Tennessee Martin
}

\begin{abstract}
This quantitative study examines linkages from online student perceptions of privacy in the satisfaction puzzle across 5 university administrative/student touch-points. The importance of categorizing the quality dimensions of online learning is paramount as learners are exposed to multiple quality touch-points prior to, during, and after the completion of an online learning experience (Ehlers, 2004; Frydenberg, 2002). Facing a greater competitive environment in student recruitment, academic institutions are increasingly aware of external evaluator rankings, accreditors, and resulting student perceptions. ANOVA results are reported, along with considerations and issues for addressing perceptions of privacy among online students.
\end{abstract}

Keywords: Online Privacy, Online Education, Electronic Service Quality

\section{INTRODUCTION}

There are more than 28,000 accredited online degree programs prepared to meet the demand of the projected $15 \%$ increase in post-secondary enrollment by 2025, according to Projections of Education Statistics to 2025 (Hussar \& Bailey, 2017, p. 24). Traditional high-touch universities struggle to meet break-even enrollment numbers when exclusively offering live courses (Lederman, 2018). Likewise, online-only universities are experiencing dramatic double-digit decreases in enrollment due to government inquiry into questionable practices and issues related to quality oversight (Haynie, 2015). Kilburn, Kilburn and Hammond (2017), Ehlers (2004) and Frydenberg (2002) highlight the importance of categorizing the various quality dimensions of online learning as learners are exposed to multiple quality touch-points prior to, during, and after the completion of online learning. One such touch-point for the online learner includes privacy. 
Research has advanced into highly-focused, quantifiable measures of online higher education program/course quality as it pertains specifically to the preparedness and quality control of faculty (Parscal \& Riemer, 2010), and rigor of instructional design, web design and course presentation (Chao, Saj \& Tessier, 2006). In addition, numerous quality assurance programs have been launched to assess overall online program, course, faculty, and student interaction quality: Institute for Higher Education Policy's Benchmarks for Success, Khan's Eight Dimensions of e-Learning Framework, and the Sloan Consortium's Five Pillars of Quality provide comprehensive online education quality assessment benchmarks (Shelton, 2011).

The privacy of administrative support offices can potentially have a significant impact on the level of security felt by users. That perception of privacy can help shape students' aggregate assessments of their educational experience (e.g. satisfaction, value, loyalty, service quality). Frydenberg points out that students' perceptions of online delivery quality are often shaped by policies, procedures and the fairness and informative communications of the university (2002). Online learning requires that students and instructors utilize technology. There is an abundance of technology choices for institutions offering online classes (Ivanovic, et al., 2013). Dennen (2015) raises the point that in education, instructors are constantly being trained on newly-introduced technology, some which focus on student privacy.

This study examined perceptions of privacy amongst students as a potential determinant of student satisfaction with various administrative departments (Admissions, Registrar, Bursar, Library Services, Information Technology Services). One-way analysis of variance demonstrates significant, positive linkages between privacy perceptions and student satisfaction with specific university functions: Registrar Office, Business Affairs Office (fee payment), Library and Information Technology Office. The study revealed an insignificant linkage between privacy perceptions and satisfaction with University Admissions. Results provide practical guidance for the university campus who attempt to integrate communications and interactions with students from pre-admissions through graduation. More specifically, this study can help universities properly identify and provide necessary resource allocation through training to the most influential administrative offices on student satisfaction.

\section{LITERATURE REVIEW}

\section{Privacy}

Privacy is the level to which the site is safe and protects customer information (Zeithaml, et al 2005). Privacy concerns are important enough to individuals participating in online activities for researchers to study (Downing, 2016; Elueze \& Quan-Haase, 2018; Ifenthaler \& Schumacher, 2016; Ivanovic, et al., 2013; Martin, Rice, \& Martin, 2016; Quinn, 2016). Many prior findings suggest that people hold many different attitudes about privacy (Dennen, 2015; Elueze \& Quan-Haase, 2018; Quinn, 2016). Martin, Rice, \& Martin (2016) did find some commonly held opinions about privacy among IT professionals. Privacy is important enough that the European Union recently updated privacy regulation to include fines that can be calculated as a percentage of global annual revenue (Robles, 2018).

Downing (2016) found that business students consider privacy rights to be important through survey results in 2006 and in 2014. Privacy is an expectation of many students (Dennen, 2015; Dennen, 2016). Students have privacy concerns about the availability of their data or course activities to others (Dennen, 2015; Ivanovic, et al., 2013). Activities undertaken by students in an online class create data (Dennen, 2015; Dennen, 2016). The authors raise important questions regarding created data with cloud services or outsourced services and the resulting ownership and vendor privacy policies (Dennen, 2015; Dennen, 2016).

Privacy is an expectation of many students (Dennen, 2015; Dennen, 2016). The reputation of a site can have a significant impact on the level of security felt by customers and aggregate perceptions of privacy. User trust is possible in situations when the site has a reputation for providing clear and truthful information as well as quality products or services. Once a rapport is built and the customer has confidence in the site, the concepts of satisfaction become possible. 


\section{Satisfaction}

Lee, Srinivasan, Trail, Lewis and Lopez (2011) find significant linkages between instructional, peer and technical support and student satisfaction in the online learning environment. The Baldrige National Quality Program (BNQP) has addressed quality in education and has laid out six overall "key areas of organizational performance" which serve as the foundation for their Education Criteria for Performance Excellence. The BNQP suggests that student perceptions regarding program and service characteristics should be routinely assessed as indicators of satisfaction, among other outcomes (p.7, BNQP, 2005). Studies have shown that high levels of service quality positively influence customer satisfaction (Cronin \& Taylor 1992; Parasuraman, Zeithaml, \& Berry 1988; Rao, Goldsby, Griffis \& Iyengar, 2011). The relationship between service quality and improved performance can provide a competitive advantage in terms of repeat sales, positive word-of-mouth, customer loyalty, and competitive product differentiation (Brown \& Swartz 1989; Cronin \& Taylor, 1992; Parasuraman, Zeithaml, \& Berry, 1988). High levels of satisfaction have been firmly established as a desirable outcome for institutions (Hallowell, 1996). Privacy is significantly, positively related to student satisfaction with various administrative departments on the university campus:

H1a: Privacy is significantly, positively related to student satisfaction with the Admissions Office.

H1b: Privacy is significantly, positively related to student satisfaction with the Registrar's Office.

H1c: Privacy is significantly, positively related to student satisfaction with the Business Affairs (fee payment) Office.

H1d: Privacy is significantly, positively related to student satisfaction with Library Services.

H1e: Privacy is significantly, positively related to student satisfaction with Information Technology Services.

\section{STUDY}

This research analyzes results of a web-based self-report survey given to students $(n=127)$ at a 4-year university taking at least one online class at an accredited public university in the Southeastern United States. The students were primarily between the ages of 23 and 47 and included both undergraduate and graduate students across over 10 degree areas. The majority of respondents were upper-division: $73.3 \%$ had Junior, Senior or Graduate standing. The survey assessed individual measures of Satisfaction regarding some common relationships students might have on university campuses with administrative departments (Admissions, Registrar, Business Affairs (fee payment), Library Services, Information Technology Services). Perceptions of privacy amongst students were also examined. Privacy scale items included (1) protecting academic information, (2) not sharing personal information with others, and (3) protecting financial records, as adapted from Zeithaml, Parasuraman and Malhotra's E-S-QUAL scale (2005) $(\alpha=.99)$.

\section{RESULTS}

Given the results that privacy was a significant independent variable for student perceptions of value based on the results of previous research, we further explored the potential impact of perceptions of privacy by using one-way ANOVA analysis using only the privacy measures as independent variables for measures of student satisfaction with each of the 5 university administrative offices (see Table 1). Oneway analysis of variance demonstrates significant, positive linkages between privacy perceptions and student satisfaction with 4 of the 5 specific university administrative offices: Registrar Office, Business 
Affairs Office (fee payment), Library and Information Technology Office. The study revealed an insignificant linkage between privacy perceptions and satisfaction with University Admissions.

\section{TABLE 1 ANOVA RESULTS}

\begin{tabular}{|l|l|l|l|l|l|l|}
\hline & & R/FTR & Adjusted R $^{\mathbf{2}}$ & F-value & t-value & Sig. \\
\hline H1a & ADMISSIONS & R & .009 & 1.395 & 8.653 & .247 \\
\hline H1b & REGISTRAR & FTR & .420 & 2.892 & 7.561 & $.038^{*}$ \\
\hline H1c & BUSINESS AFFAIRS & FTR & .117 & 6.729 & 7.339 & $.000^{*}$ \\
\hline H1d & LIBRARY SERVICES & FTR & .102 & 5.918 & 7.948 & $.001^{*}$ \\
\hline H1e & IT SERVICES & FTR & .062 & 3.880 & 7.746 & $.011^{*}$ \\
\hline
\end{tabular}

*Significant at .05 level of significance

\section{DISCUSSION}

Our results found that student perceptions of privacy have a significant impact on the satisfaction students have with multiple touch-points across a university's campus. Interestingly, the most significant impact of privacy on online learner satisfaction surrounds administrative offices learners use after being admitted to a university. The most obvious implication being that universities and colleges must place value on security and privacy across the entire campus, with specific training for administrative offices that enrolled online learners may encounter. Results provide practical guidance for the university campus who attempt to integrate communications and interactions with students from pre-admissions through graduation. This study can help universities properly identify their most impactful administrative touchpoints. Moreover, universities can then provide targeted privacy training to their most influential administrative offices and expect to sustain or improve online student satisfaction.

Appropriate privacy training will need to involve investing in measures to protect student privacy. The information technology or information systems area of colleges and universities may need to ask questions to seek out information about practices to address privacy concerns, and they may need support from administration leaders to fund initiatives that can help protect privacy. Students interact with university employees from many areas or departments such as admissions, financial aid, bursars and faculty members. In order for universities and colleges to manage privacy concerns, there must be training available to employees so that they can do their part to protect student privacy and support student perceptions of those efforts. One suggestion offered in prior research is to help students learn more about privacy (Dennen, 2015; Dennen 2016).

Greenaway and Chan (2013) point out that organizations can view addressing privacy concerns as an obligation or an opportunity to better serve stakeholders. However, while privacy is significantly related to the value and satisfaction students have with their online educational experiences, privacy is not enough to drive student satisfaction. Our results may suggest that while colleges and universities need to do well to address privacy concerns, it is unlikely that colleges and universities will be able to create competitive advantages through their handling of privacy concerns and expectations. One reason for this observation is that colleges and universities in the US are required to comply with the Family Educational Rights and Privacy Act (Dennen, 2015).

In addition to compliance with privacy rules and regulations, higher education institutions need to use care when selecting vendors for information technology services. This also includes cloud services and infrastructure services provided by external entities (Dennen, 2015). One implication for vendors is that they must not only practice good information security to protect privacy, but they may also benefit if they are able to address privacy and security concerns. Additional privacy concerns may arise when external platforms or technology are applied to learning environments that are not focused solely towards education (Dennen, 2015). The results of our study found that privacy concerns are significant to student 
evaluations of their online education experience. As previously established, quality perceptions are critical components of the global value assessment made by online students (Kilburn, et al 2017). This research works to shed light on the impact of critical touchpoints, directly controllable by academic institutions, which lead to student perceptions of satisfaction and ultimately choice, value, retention. The impact for higher education institutions offering online education is that students will be more satisfied with their online learning experiences if their concerns about privacy across university administrative offices are perceived to be addressed.

Our results do not suggest or imply that privacy alone can generate student satisfaction with online learning. One limitation of our study is that the students who responded to the survey were all students at one particular university. Some ad-hoc analyses were undertaken to find if there were differences in the importance of privacy to students based on whether the students were in a graduate program or an undergraduate program. The $\mathrm{Chi}^{2}$ differences analysis actually found that the difference between graduate student and undergraduate student privacy and satisfaction perceptions were not statistically significant. Additionally, we wanted to learn if there were differences based on the area of the field of study of students. We did find there to be some statistically significant differences based on the area of the field of study. One interpretation of this result is that it may suggest that students in different fields have differing expectations and perceptions of privacy.

\section{REFERENCES}

BNQP (Baldrige National Quality Program). (2005). Baldrige Education Criteria for Performance Excellence, National Institute of Standards and Technology: Gaithersburg, MD. Retrieved from www.quality.nist.gov/Education_Criteria.htm.

Brown, S., \& Swartz, T. (1989). A gap analysis of professional service quality. Journal of Marketing, 53(2), 92-98.

Chao, Y., Lee, G., \& Ho, Y. (2006). Customer loyalty in virtual environments: an empirical study in e bank. AIP Conference Proceedings, 1148(1), 497-500.

Cronin, J. J., \& Taylor, S.A. (1992). Measuring service quality: a reexamination and extension. Journal of Marketing, 56(3), 55-68.

Dennen, V.P. (2015). Technology transience and learner data shifting notions of privacy in online learning. The Quarterly Review of Distance Learning, 45-59.

Dennen, V. P. (2016). Ownership of digital course artifacts who can access and use your words, images, sounds, and clicks? The Quarterly Review of Distance Education, 5-19.

Downing, C. E. (2016). Privacy and the information age: a longitudinal view. Journal of International Technology and Information Management, 33-45.

Ehlers, U. D. (2004). Quality in e-Learning from a Learner's Perspective. Third EDEN Research Workshop: Oldenburg, Germany.

Elueze, I., \& Quan-Haase, A. (2018). Privacy attitudes and concerns in the digital lives of older adults: westin's privacy attitude typology revisited. American Behavioral Scientist, 1372-1391.

Frydenberg, J. (2002). Quality standards in e-learning: a matrix of analysis. The international review of research in open and distance learning, 3(2). Retrieved from http://www.irrodl.org/index.php/irrodl/article/viewArticle/109/189.

Greenaway, K. E., \& Chen, Y. E. (2013). Designing a customer information privacy program aligned with organizational priorities. MIS Quarterly Executive, 137-150.

Hallowell, R. (1996). The relationships of customer satisfaction, customer loyalty, and profitability: an empirical study. International Journal of Service Industry Management, 7(4), $27-42$.

Haynie, D. (2015). Study shows sluggish online learning growth for second year. US News \& World Report. Retrieved from: http://www.usnews.com/education/onlineeducation/articles/2015/02/05/study-shows-sluggish-online-learning-growth-for-second-year. 
Hussar, W., \& Bailey, T. (2017). Projections of Education Statistics to 2025 (NCES 2017-019), U.S. Department of Education: Washington, DC. Retrieved from https://nces.ed.gov/pubs2017/2017019.pdf

Ifenthaler, D., \& Schumacher, C. (2016). Student perceptions of privacy principles for learning analytics. Educational Technology Research \& Development, 923-938.

Ivanovic, M., Putnik, Z., Komlenov, Z., Welzer, T., Holbl, M., \& Schweighofer, T. (2013). Usability and privacy aspects of Moodle: students' and teachers' perspective. Informatica, 221.

Kilburn, A.J., Kilburn, B.R., \& Hammond, K. (2017). The role of quality in online higher education. Journal of Higher Education Theory and Practice, 17(7), 80-86.

Lederman, D. (2018). Market changes, missteps \& marylhurst's closure. Inside Higher Ed. Retrieved from https://www.insidehighered.com/digital-learning/article/2018/05/30/universitys-closureand-its-implications-online-learning-adult.

Lee, S., Srinivasan, S., Trail, T., Lewis, D., \& Lopez, S. (2011). Examining the relationship among student perception of support, course satisfaction, and learning outcomes in online learning. Internet and Higher Education 14(3), 158-163.

Martin, N., Rice, J., \& Martin, R. (2016). Expectations of privacy and trust: examining the views of IT professionals. Behaviour \& Information Technology, 500-510.

Parasuraman, A., Zeithaml, V.A., \& Berry, L.L. (1988). SERVQUAL: a multiple-item scale for measuring service quality. Journal of Retailing, 64(1), 12-40.

Parscal, T., \& Riemer, D. (2010). Assuring quality in large-scale online course development. Online Journal of Distance Learning Administration, 8(2), Summer.

Quinn, K. (2016). Why we share: a uses and gratifications approach to privacy regulation in social media use. Journal of Broadcasting \& Electronic Media, 61-86.

Rao, S., Goldsby, T., Griffis, E., \& Iyengar, D. (2011). Electronic logistics service quality (e-LSQ): its impact on the customer's purchase satisfaction and retention. Journal of Business Logistics, $32(2), 167-179$.

Robles, M. (2018). 5 Data privacy rights introduced by GDPR. Risk Management, 12-13.

Shelton, K. (2011). A review of paradigms for evaluating the quality of online education programs. Online Journal of Distance Learning Administration, 4(1), Spring.

Zeithaml, V.A., Parasuraman, A. \& Malhotra, A. (2005). E-S-QUAL: a multiple item scale for assessing electronic service quality. Journal of Service Research, 7(3), 213-233. 